\title{
Percepção Científica do Direito
}

Reis FRIEDE ${ }^{\bullet}$

\begin{abstract}
Resumo: $O$ presente artigo analisa, inicialmente, a posição majoritária da doutrina segundo a qual o Direito se constitui em autêntica e genuína ciência autônoma, abordando o conceito de ciência, a classificação binária das ciências, bem como outras classificações relativas às ciências, passando, a seguir, à classificação da Ciência do Direito, objetivando extrair os importantes ensinamentos derivados de tal percepção. Posteriormente, passa-se à análise da axiologia jurídica e projeção comportamental do Direito, da tridimensionalidade do Direito, da caracterização particular da Ciência do Direito e, por fim, das especificidades da Ciência Jurídica.
\end{abstract}

Palavras-chave: Direito; Ciência Autônoma; Classificação; Axiologia.

Não obstante a tese segundo a qual o Direito se constitui em efetivo ramo científico ter sido negligenciada no passado por expressiva parcela de estudiosos, na atualidade contemporânea é, no mínimo, majoritária a posição doutrinária que entende o Direito como autêntica e genuína Ciência Autônoma.

- Catedrático, ex-Membro do Ministério Público, Mestre e Doutor em Direito, Professor-Coordenador da Escola de Pós-Graduação em Direito da UniverCidade e Professor-Coordenador dos Cursos de Graduação em Direito da UniverCidade - Campus Centro e autor de inúmeras obras jurídicas, dentre as quais "Ciência do Direito, Norma, Interpretação e Hermenêutica Jurídica", $4^{\mathrm{a}}$ edição, Forense Universitária, 2001, RJ (189 ps.) e "Vícios de Capacidade Subjetiva do Julgador: Do Impedimento e da Suspeição do Magistrado nos Processos Civil, Penal e Trabalhista", 3ª edição, Forense, 2001, RJ (469 ps.).E-mail: reisfriede@hotmail.com 
Ainda que se possa discutir se o Direito constitui-se na própria ciência, em sua descrição conceitual, ou, ao contrário, restringe-se apenas ao objeto de uma ciência (a chamada Ciência do Direito), a verdade é que, no presente momento evolutivo, poucos são os autores que ousam desafiar a visão dominante do Direito como ciência e suas principais conseqüências, especialmente após o advento - e, sobretudo, a leitura técnica da notável obra de Hans Kelsen, Teoria Pura do Direito, em que o autor logrou demonstrar, na qualidade de mentor do racionalismo dogmático (normativismo jurídico), a pureza jurídica do Direito em seu aspecto tipicamente científico.

Mesmo assim, entre nós ainda existem aqueles que simplesmente defendem o ponto de vista do Direito como uma forma não-científica, desafiando não só o caminho lógicoevolutivo do estudo do Direito, mas, particularmente, a acepção mais precisa (e correta) do vocábulo ciência.

"(...) não é rigorosamente científico denominar o Direito de ciência. (...). As pretensas ciências sociais, com ranço comtiano, onde se costuma incluir o Direito (...) não oferecem princípios de validez universal que lhes justifiquem a terminologia (...)". (PAULINO JACQUES in Curso de Introdução ao Estudo do Direito, ps. 10/11)

"O Direito não é ciência, mas arte; como também ramo da moral" (GENY in Science et Téchnique en Droit Privé Positif, 2a. édiction, Tome I, Paris, 1927, ps.69/71 e 89)

"As regras do Direito são preceitos artísticos, normas para fins práticos, determinações ordens, que se impõem à vontade. Não se confundem com as afirmações científicas, que se dirigem à inteligência." (PEDRO LESSA in Estudos de Philosophia do Direito, Rio, 1912, p.46) 
PERCEPÇÃO CIENTÍFICA DO DIREITO

\section{Conceito de Ciência}

A questão central, nesse contexto de atuação, ao que tudo indica, parece ser, sob o prisma de sua própria especificidade, os múltiplos e variáveis conceitos de ciência, bem como as possíveis e diferentes traduções do vocábulo em epígrafe.

Nesse sentido, resta oportuna a lição de Tércio Sampaio Ferraz Jr. (in Direito, Retórica e Comunicação, Saraiva, SP, 1973, ps. 159/160) para quem "a expressão ciência não é unívoca; não obstante de com ela se pretender designar um tipo específico de conhecimento, não há um critério único e uniforme que determine sua extensão, natureza e caracteres, devido ao fato de que os vários critérios têm fundamentos filosóficos que extravasam a prática científica."

De qualquer sorte, o que caracteriza a ciência, na acepção atual, não pode ser, em nenhuma hipótese, como deseja Paulino Jacques, uma pretensa e utópica validez universal de seus princípios, independentemente de meridianos e paralelos, uma vez que, de forma absolutamente diversa, a noção contemporânea de ciência reside no escopo próprio de sua atuação, ou seja, na busca, constante e permanente, pela verdade (ou, ainda, em outras palavras, na perene explicação evolutiva dos diversos fenômenos naturais e sociais). ${ }^{1}$

Em essência, - é oportuno ressaltar -, inexiste, de forma insofismável, a efetiva possibilidade de se ter fato gerando normas de validade sinérgica, acima de qualquer possibilidade de contestação no espectro temporal-evolutivo.

Muito pelo contrário, o que a ciência realiza, no âmbito de sua atuação, é exatamente conceber, caracterizando e criando através de interpretações próprias (porém, com necessário escopo de generalização), a melhor explicação de um dado fenômeno particular (natural ou social), em um considerado momento histórico em que aspectos culturais, geográficos, organizacionais, etc, necessariamente possuem sua esfera maior ou menor - de influência. ${ }^{2}$

A concepção básica de Ciência (incluindo seu conceito específico), por efeito consequente, não pode considerar a 
existência de incontestes e permanentes princípios de validez universal, tendo em vista que a validade intrínseca dos princípios e pressupostos científicos são sempre mutáveis no tempo e no espaço, em decorrência da própria e necessária evolução dos conceitos científicos. ${ }^{3}$

Por efeito consequente, a ciência não pode, sob pena de sublime subversão lógico-conceitual, ser encarada como algo que se traduz por uma verdade absoluta, mas, ao contrário, necessariamente deve ser entendida como algo que busca, de forma constante e permanente, a verdade (em sua acepção plena), aproximando-se cada vez mais da mesma, porém sem nunca poder atingi-la, ou mesmo tangenciá-la com plena segurança. $^{4}$

\section{Classificação Binária das Ciências}

Se é plenamente correto afirmar que as ciências, de modo geral, não se traduzem em verdades absolutas (ou, sob outra ótica, em princípios imutáveis e intangíveis de validez permanente e universal), mas apenas e limitadamente na busca incansável por estas mesmas verdades (no sentido da explicação correta e absoluta para cada fenômeno natural ou social (cultural)), não menos acertada constitui a afirmação segundo a qual o raciocínio binário humano se constitui no principal fator limitante do próprio desenvolvimento científico. ${ }^{5}$

Como a contingência de superação da limitação binária tem se mostrado, nos inúmeros séculos de desenvolvimento da humanidade, tarefa impossível de ser concretizada, restou, de forma inexorável, ao gênero humano conceber e adaptar todos os modelos de desenvolvimento científico a esta forma única e exclusiva de pensar.

Por efeito consequente, todas as classificações de cunho científico forçosamente tiveram de se adaptar, e efetivamente se adaptaram, à imposição do binarismo, inclusive, sob esta ótica, a própria classificação das ciências em seu sentido amplo.

Nesse contexto, as ciências, quanto ao seu objeto, 
passaram, de maneira amplamente majoritária, a ser classificadas em dois principais grupos: as denominadas ciências da natureza (cujo foco de observação são fenômenos naturais) e as chamadas ciências da sociedade (cujo foco de observação cinge-se a fenômenos sociais e culturais). As ciências naturais, por sua vez, passaram a admitir uma subdivisão peculiar em ciências do macrocosmos (cujo foco de observação são fenômenos naturais externos aos seres vivos) e em ciências do microcosmos (cujo foco de observação são fenômenos naturais internos aos seres vivos), ao passo que as ciências sociais, por seu turno, passaram a acolher a subdivisão em ciências não-hermenêuticas (ou não-comportamentais) e em ciências hermenêuticas (ou comportamentais).

No primeiro grupo (ciências naturais do macrocosmos), encontramos a Física, a Química, a Astronomia etc.; no segundo grupo (ciências naturais do microcosmos), nos deparamos com a Medicina, a Biologia, etc.; no terceiro grupo (ciências sociais nãohermenêuticas) achamos a Sociologia, a Antropologia, etc.; e, finalmente, no quarto grupo (ciências sociais hermenêuticas), encontramos o Direito. ${ }^{6}$

Muito embora os menos avisados possam questionar onde estaria, neste espectro classificatório, posicionada a Matemática, a verdade é que esta pseudociência, por não possuir o escopo próprio de atuação das ciências (ou seja, a valoração intrínseca (e interpretativa) de um fato (natural ou social), concebendo uma norma explicativa (inerente ao mundo real) ou de projeção (inerente ao mundo cultural)), melhor se encontra classificada como genuína linguagem científica ou, como preferem alguns, efetiva ciência instrumental. 


\section{Diagrama 1:}

Classificação das Ciências (Quanto ao Objeto de Observação)

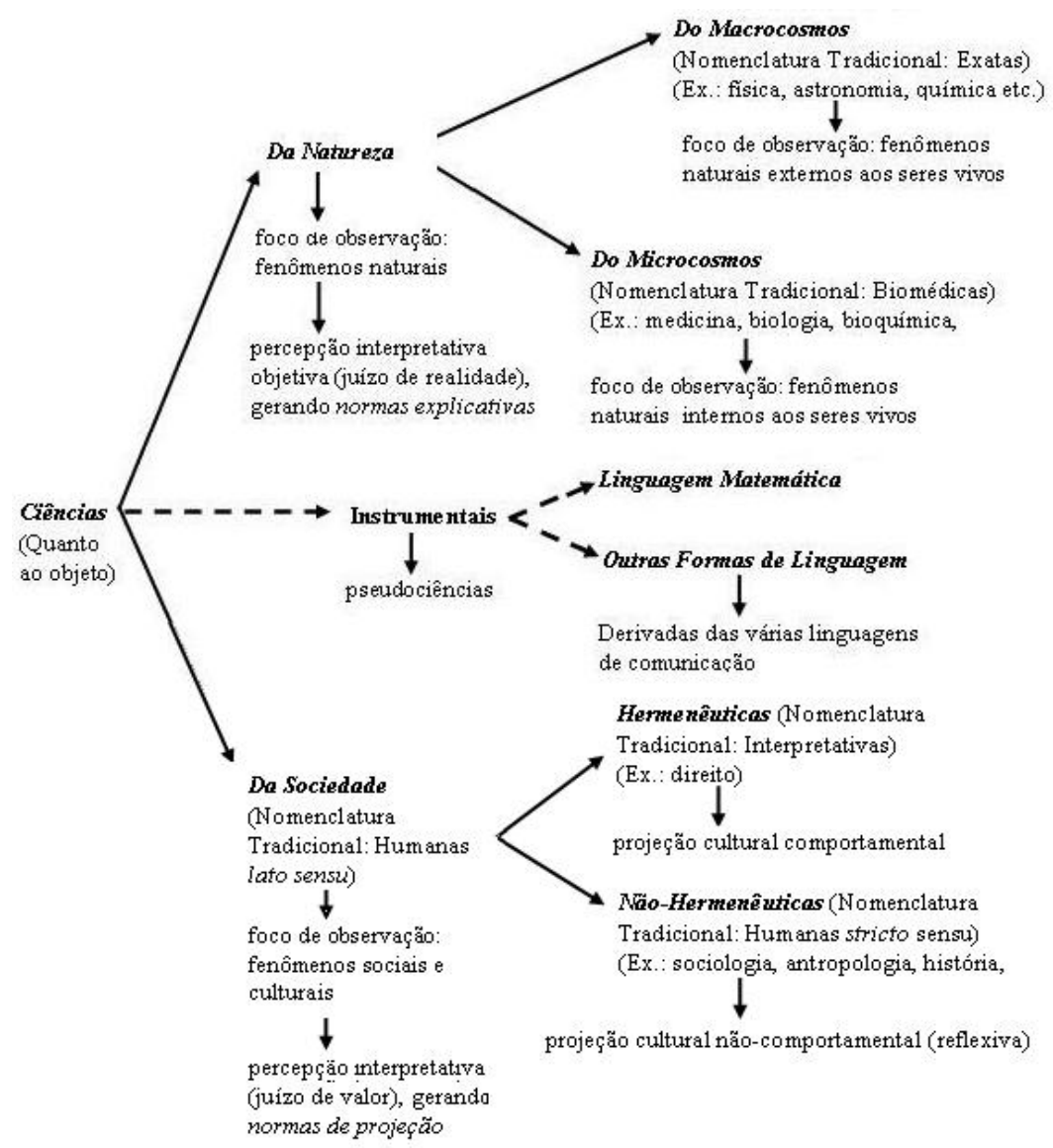


PERCEPÇÃO CIENTÍFICA DO DIREITO

\section{Outras Classificações Relativas às Ciências}

Não obstante a consagrada classificação binária das ciências, resta oportuno consignar que, no espectro histórico-evolutivo, como bem leciona Maria Helena Diniz em seu Compêndio de Introdução à Ciência do Direito (12a ed., Saraiva, SP, 2000, ps. 22-26), muitos autores ensaiaram algumas classificações, hoje, de modo geral, reputadas primitivas (e, portanto, ultrapassadas), que partem de outros pressupostos lógicos.

Augusto Comte, (Cour de Philosophie Positive, Paris, 1949), por exemplo, optou por classificar as ciências em abstratas (teóricas ou gerais) e concretas (particulares ou especiais).

No primeiro grupo comtiano, como bem salienta Maria Helena Diniz (ob. cit., p. 23), estariam as ciências que estudam as leis gerais que norteiam os fenômenos da natureza, sendo-lhes aplicável os critérios da dependência dogmática (que consiste em agrupar as ciências, de modo que cada uma delas se baseie na antecedente, preparando a consequente), da sucessão histórica (que indica a ordem cronológica de formação das ciências, partindo das mais antigas às mais recentes) e de generalidade decrescente e complexidade crescente (que procede partindo da mais geral para a menos geral e da menos complexa para a mais complexa), compreendendo, neste particular, a matemática (ciência dos números e da grandeza, a mais simples e universal, posto que só se refere às relações de quantidade, embora seja a mais geral porque se estende a todos os fenômenos), a astronomia (física celeste ou mecânica universal, ciência que estuda as massas materiais que existem no universo), a física (ciência que se ocupa dos fenômenos físicos, ou seja das forças da natureza), a química (físico-química, ciência que tem por objeto a constituição dos corpos particulares), a biologia (física-biológica, ciência que estuda os corpos complexos que se apresentam com vida) e a sociologia (físico social, ciência das relações sociais que se dedica a acompanhar a vida social do homem).

No segundo grupo desta classificação, por seu turno, encontrariam-se as ciências derivadas em que a tônica seria a descrição concreta dos fenômenos abstratos estudados nas ciências teóricas ou gerais. Desta feita, a botânica e a zoologia seriam ciências concretas derivadas da biologia, ao passo que o Direito seria uma ciência concreta derivada da sociologia. 
Diagrama 2: Classificação das Ciências Segundo Augusto Comte

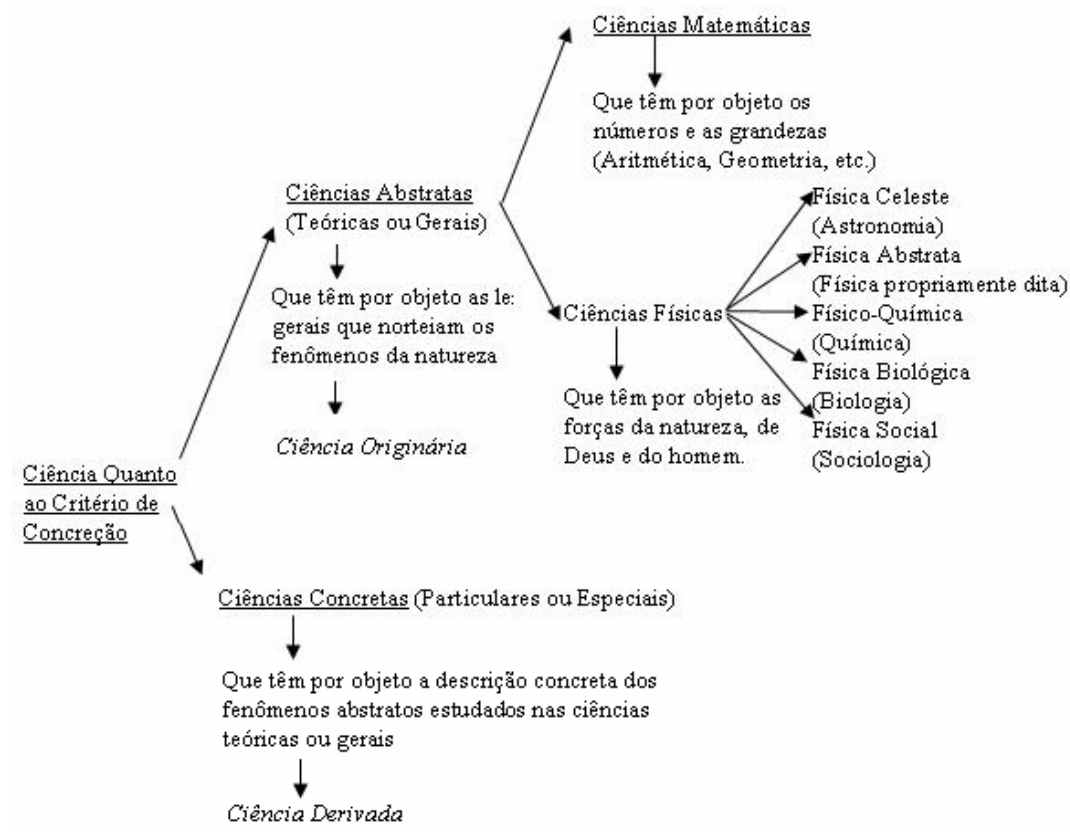

Wilhem Dilthey (Introduction a L'etude des Sciences Humaines, Paris, 1942), inspirado, como bem lembra Maria Helena Diniz (ob. cit., p. 24), na classificação de ciência de AMPÉRE, optou, por sua vez, em distinguir ciências da natureza (que se ocupam dos fenômenos físico-naturais, empregando o método da explicação fática) e ciências do espírito (ciências noológicas ou culturais na nomenclatura de Rickert), estas subdivididas em ciências do espírito subjetivo (psicológicos, que têm por objeto o mundo pensamento) e em ciências do espírito objetivo (culturais, que descrevem e analisam a realidade histórica e social como produto das ações humanas).

Nesse contexto classificatório, encontraríamos na primeira divisão a física, a química, a biologia, etc., ao passo que, na segunda divisão, a psicologia (espírito subjetivo) e a sociologia e o direito (espírito objetivo), entre outras. 


\section{Diagrama 3:}

Classificação das Ciências Segundo Wilhem Dilthey (e Ampère)

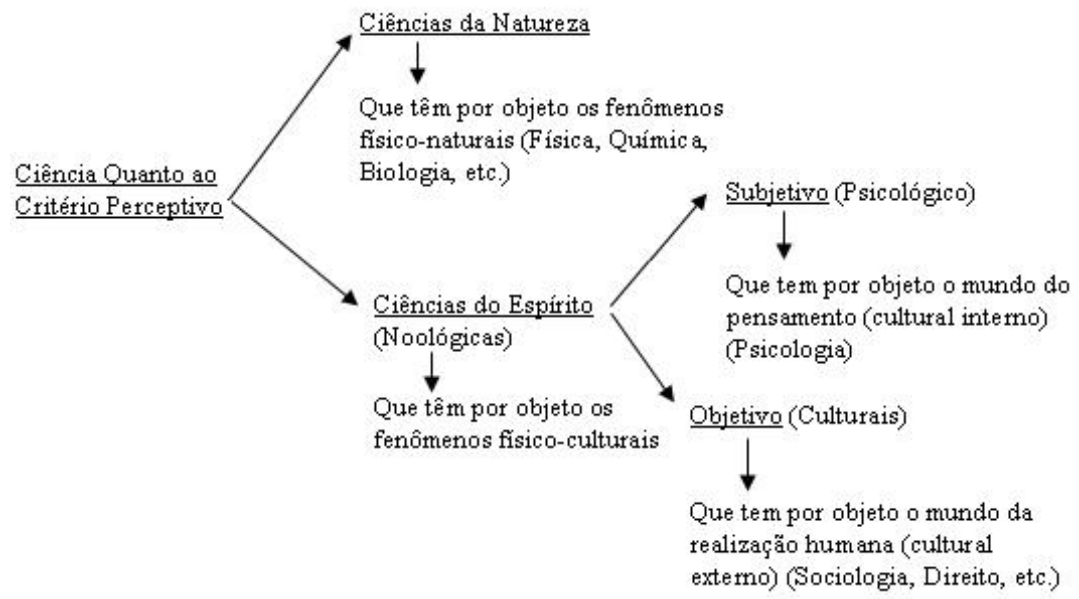

Aristóteles, baseando-se no critério ficcional, por seu turno, preferiu dividir as ciências em teórica ou especulativa (limitadas à reprodução cognitiva da realidade), e práticas (que tem por objeto o conhecimento para a orientação de ações e comportamentos).

Dentre as ciências teóricas, distinguiu-se, conforme o grau de abstração inerente a cada uma delas, as ciências físicas ou naturais (incluindo a percepção da natureza originária (realidade natural) e da natureza transformada pelo homem (realidade cultural)), as ciências matemáticas ou formais (atinentes ao mundo quantitativo numérico (aritmética) e extensivo (geometria)) e as ciências metafísicas (ontológicas, relativas ao ser enquanto ser, ocupando-se com noções de causa e efeito).

Já no grupo das ciências práticas, existiriam as ciências morais ou ativas que objetivam dar normas ao agir, procurando dirigir a atividade interna e pessoal do homem, buscando atingir o bem comum) - onde estaria inserido o Direito -, e as ciências factivas e produtivas (que visam dar normas ao fazer, procurando dirigir a atividade externa e pessoal do homem, buscando atingir o belo (ciências artísticas) ou o útil (ciências técnicas)). 


\section{Diagrama 4:}

Classificação das Ciências Segundo Aristóteles

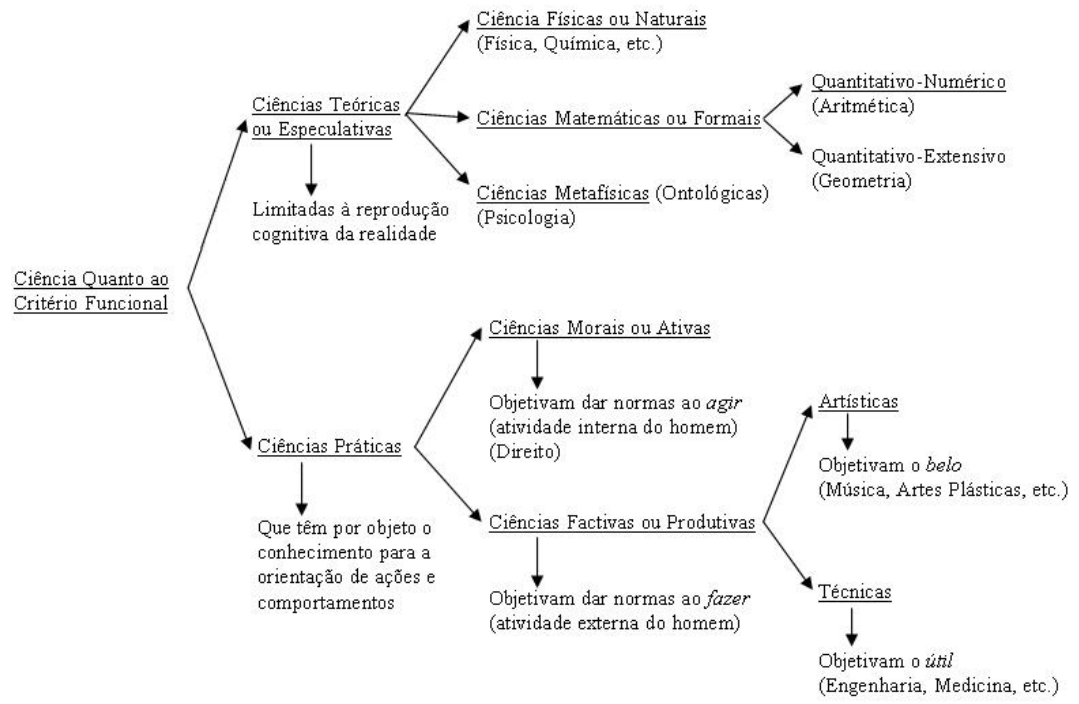

De qualquer sorte, - e independentemente de outras considerações -, vale frisar que, sob uma certa ótica, todas essas diferentes classificações também atendem, a exemplo da doutrina mais contemporânea a propósito do tema, a uma concepção binária, ainda que, de modo inevitável, restrita, por sua vez, a uma percepção menos desenvolvida (avançada) do fenômeno epistemológico em seu sentido amplo. 


\section{Normas da Natureza (Juízo de Realidade) e Normas da Cultura (Juízo de Valor)}

A moderna concepção classificatória binária, todavia, não pode ser plena e satisfatoriamente entendida, em sua inteireza, sem a necessária compreensão da origem última da própria dicotomia intrínseca que existe na distinção básica e fundamental entre as ciências naturais e sociais (culturais), na qualidade de incontestes circunstâncias originárias que se operam como verdadeiras explicações lógico-distintivas.

Essas inerentes características circunstanciais aludem, sobretudo, às diferentes percepções normativas que se deduzem a partir da observação dos mais diversos fenômenos naturais e sociais (culturais), o que torna, por via de conseqüência, o seu estudo indiscutivelmente fundamental para a perfeita compreensão do Direito como ciência social (cultural).

Desta feita, o primeiro passo, sob esta ótica analítica, é procurar estabelecer claramente a indubitável diferença entre as regras derivadas da simples observação da natureza, - que retratam a realidade perceptível do mundo como ele se apresenta (mundo do ser) -, produzindo os chamados

"juízos de realidade", das regras derivadas da percepção intelectual e criativa do homem, - que, ao contrário, traduzem a percepção axiológica do ser social e criativo -, produzindo os denominados "juízos de valor". "

As normas da natureza, inerentes ao juízo de realidade (valoração factual perceptiva de caráter objetivo), como se pode facilmente deduzir, são estudados pelas chamadas ciências naturais, por intermédio de suas duas vertentes: macrocosmos (relativa aos aspectos factuais da realidade observável externa aos seres vivos) e microcosmos (relativa aos aspectos factuais da realidade observável interna aos seres vivos). 
Já as normas da cultura, inerentes ao juízo de valor (valoração perceptível de caráter subjetivo), ao contrário, correspondem às denominadas ciências sociais (culturais) que se subdividem, por seu turno, em ciências não-hermenêuticas (em que os juízos de valor são procedidos sobre fatos sociais observados, reunindo, pois, normas derivadas de simples percepção axiológica e reflexiva dos fenômenos ocorridos no mundo cultural, tais como as normas sociológicas, históricas, econômicas, etc.) e em ciências hermenêuticas (em que os juízos de valor se adicionam a uma projeção de obrigatoriedade de comportamento na busca da preservação de valores e que, por esta razão, são necessariamente reinterpretadas hermeneuticamente).

Vale registrar, por oportuno, que outros autores também têm ensaiado outras classificações a respeito do tema, ainda que, de um modo geral, aludam, como não poderia deixar de ser, as inexoráveis diferenças entre as normas da natureza (derivadas do juízo de realidade e inerentes ao mundo do ser) e as normas de cultura (derivadas do juízo de valor e inerentes ao mundo do dever-ser). Nesse particular, resta, como ilustração, expressamente aludir à classificação de Hermes De Lima (Introdução à Ciência do Direito, 27ª ed., Freitas Bastos, RJ, 1983), que procurou estabelecer uma classificação, segundo a conduta humana, em normas técnicas (derivadas do juízo de realidade e inerentes ao mundo do ser) e em normas éticas (derivadas do juízo de valor e inerentes ao mundo do dever-ser). 


\section{Diagrama 5: Concepção Estrutural Normativa: Normas da Natureza} (Juízo de Realidade) e Normas da Cultura (Juízo de Valor)

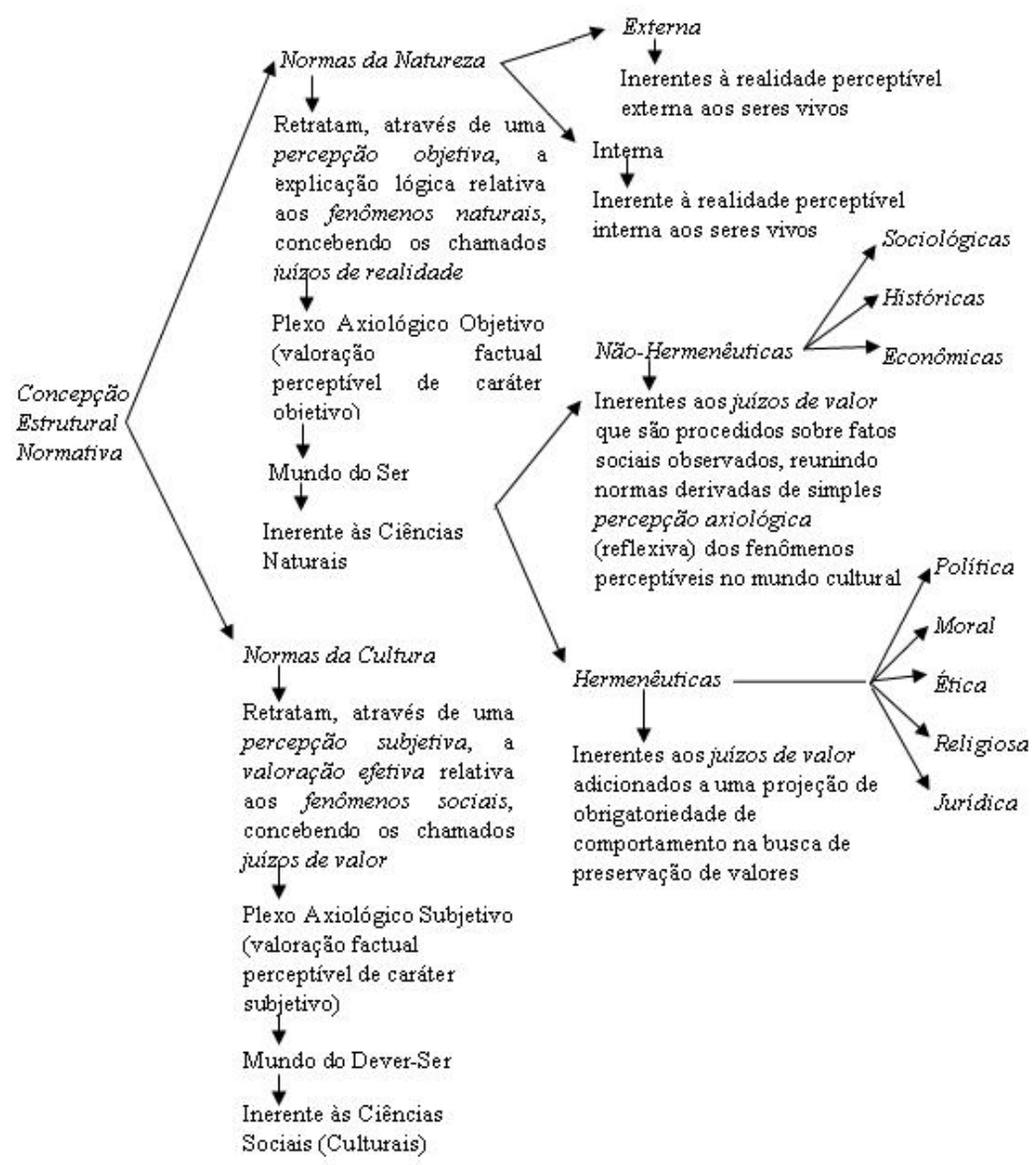

HISTÓRIA, São Paulo, 28 (2): 2009 


\section{Classificação da Ciência do Direito}

Como o objeto precípuo de nosso trabalho restringe-se ao estudo do Direito, mister que, a partir de um amplo quadro ilustrativo (já perfeitamente delineado), nos limitemos à classificação do Direito, objetivando, desta feita, extrair os importantes ensinamentos derivados desta percepção.

Neste diapasão, resta fundamental assinalar que, num espectro analítico mais adequado, a Ciência do Direito tem sido corretamente classificada como efetiva ciência social, de nítida feição hermenêutica, considerando, especialmente, não só possuir foco de observação em fenômenos sociais e culturais, mas, sobretudo, por desenvolver um sistema peculiar de interpretação de fatos sociais e culturais que não se limita, de nenhuma maneira, à simples valoração intrínseca dos mesmos, concebendo norma (fase legislativa), mas, ao contrário, permite ultrapassar a concepção fundamental interpretativa, reprocessando a conclusão (ou, em outras palavras, a própria norma) e concebendo, desta feita, uma segunda norma (de aplicação) no contexto de um sinérgico processo hermenêutico (fase judicial). ${ }^{8}$

Todavia, não obstante a inerente complexidade do assim concebido processo hermenêutico, o Direito, sob o prisma classificatório, não pode se restringir (e de fato não se restringe) à simples designação de ciência social hermenêutica, posto que a denominada ciência jurídica também se caracteriza, de forma diversa das demais ciências, por ser uma ciência particular de projeção comportamental (ou, como preferem alguns autores, ciência de projeção de um mundo ideal (meta do dever-ser)) e por ser uma ciência inexoravelmente axiológica (valorativa). ${ }^{9}$ 
PERCEPÇÃO CIENTÍFICA DO DIREITO

\section{Axiologia Jurídica e Projeção Comportamental do Direito}

Inegavelmente, as características axiológicas e de projeção comportamental (meta do dever-ser) do Direito, muito mais do que a própria vertente hermenêutica, foram responsáveis, por muitos anos (e mesmo séculos), pela grande dúvida no tocante ao específico posicionamento enciclopédico do Direito. Havia no passado remoto razoáveis dúvidas (e algumas com sobrevida mesmo no passado recente) a respeito dessas características particulares da Ciência Jurídica, notadamente no que alude à sua específica operacionalidade prática, forjando, em conseqüência, uma forte incompreensão quanto à efetiva possibilidade de se ter, no espectro classificatório, uma autêntica ciência social de projeção de um mundo ideal, a partir de premissas valorativas (de cunho nitidamente axiológico), inerentes a um quadro de idéias (com forte feição ideológica), presentes e decompostas no mundo real.

Entretanto, o que aparenta ter sido dúvida primaz no passado parece ter se transformado em inconteste certeza no presente, permitindo que o Direito - a par de toda a sorte de inegáveis especificidades - se posicione, com invejável segurança, na atualidade contemporânea, em um tipo particular de ciência, com características especiais (hermenêutica, comportamental (projeção de um mundo ideal (meta do deverser)) e axiológica), mas nem por isso distante do factum característico fundamental de todas as ciências, ou seja, a busca permanente e contínua pela verdade, através da interpretação de fatos (naturais ou sociais), por intermédio da necessária e insuperável valoração intrínseca de um dado fenômeno, originando uma norma ou tese (explicativa e/ou comportamental).

(Informações complementares e detalhes a respeito do tema podem ser pesquisados em nossa obra Ciência do Direito, Norma, Interpretação e Hermenêutica Jurídica, $3^{a}$ ed., Rio de Janeiro, Forense Universitária, 2000, ps. 1-38). 
Diagrama 6: Caracterização da Ciência Hermenêutica do Direito

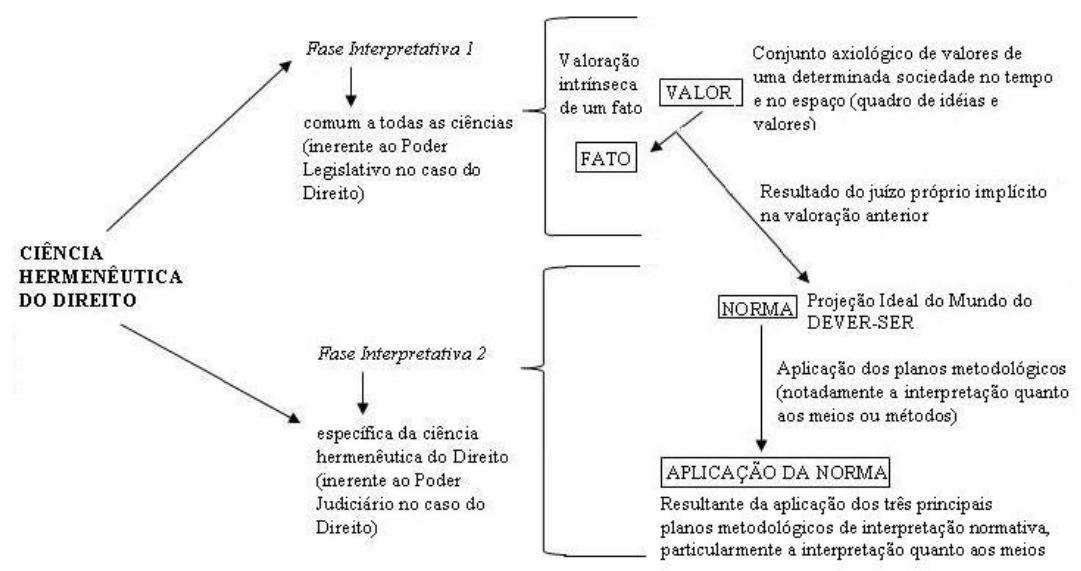

\section{Tridimensionalidade do Direito}

Não obstante toda a sorte de considerações que permitem uma verdadeira multiplicidade de pontos de vista a respeito do Direito como ciência, - particularmente o próprio conceito de ciência, que de sua matriz original e restritiva ("ciência é um complexo de enunciados verdadeiros, rigorosamente fundados e demonstrados, com um sentido limitado, dirigido a um determinado objeto") evoluiu para uma concepção contemporânea mais ampla e consentânea ("ciência é a busca da verdade (explicativa de uma realidade inerente ao mundo do ser ou projetativa de uma percepção cultural inerente ao mundo do dever-ser) -, é fato que, em seu caráter estrutural, a denominada Ciência Jurídica apresenta-se através de uma nítida 
feição tridimensional, transcendente, em todos os casos, às diversas concepções epistemológico-jurídicas relativas à cientificidade do conhecimento jurídico.

Desta feita, - independente da particular concepção doutrinária de Miguel Reale -, o Direito, como qualquer ciência, constitui-se, em último grau, em uma resultante final da percepção interpretativa (de índole subjetiva, inerente ao seu correspondente juízo de valor, relativo ao denominado mundo do dever-ser, dotado de significação cultural) de um dado fato social, traduzindo necessariamente uma concepção normativa (cultural) de projeção comportamental e de natureza hermenêutica.

Por efeito consequente, a caracterização do Direito, como inconteste realidade científica, em sua vertente tridimensional, apenas reflete, em linhas gerais, o caráter comum da equação que sempre se constrói por intermédio da percepção interpretativa de um fato (valoração factual) concebendo uma norma resultante; sendo certo, sob este prisma, que as diferentes ciências e suas respectivas classificações se operam a partir, sobretudo, das duas diferentes possibilidades de percepções interpretativas de um dado fato produzindo normas finalísticas: de caráter objetivo (juízo de realidade inerente ao mundo do ser sobre fatos naturais, traduzindo normas (reais) explicativas) ou de caráter subjetivo (juízo de valor inerente ao mundo do dever-ser sobre fatos sociais, traduzindo normas (culturais) de projeção comportamental (hermenêutica) ou nãocomportamental). 
Diagrama 7: Estrutura Tridimensional das Ciências

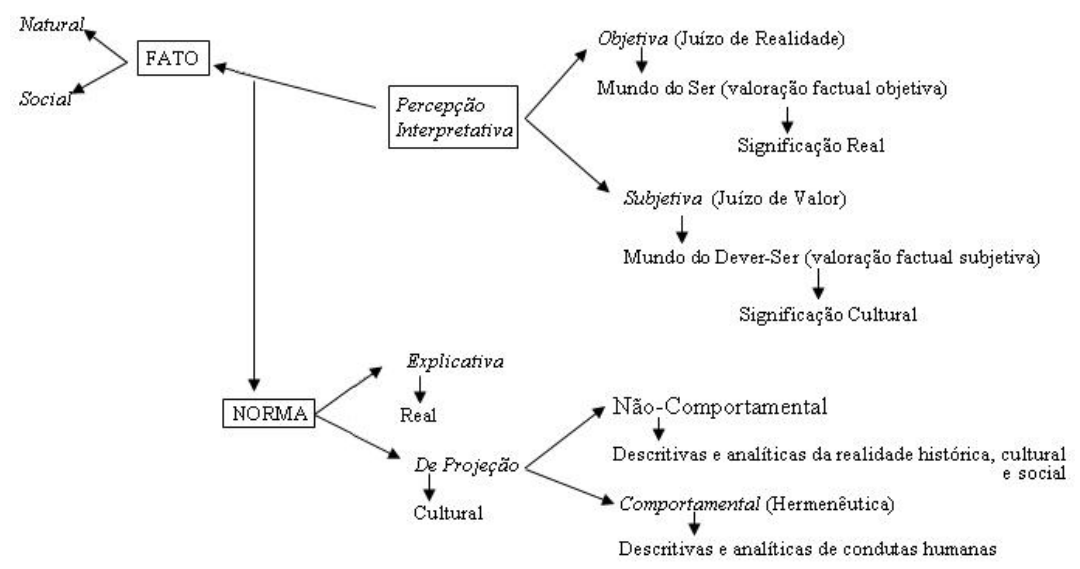

\section{Estrutura Tridimensional do Direito}

O tridimensionalismo, essencialmente, constitui-se, portanto, em uma característica estrutural inerente a todas as ciências, - e não, como podem supor os menos avisados, a uma particularidade da Ciência do Direito -, ainda que sejamos obrigados a reconhecer que a denominada visão tridimensional de Miguel Reale, neste aspecto, transcenda à concepção básica da tríade Fato-Valor-Norma, comum a toda construção científica, para também abranger aspectos associados, próprios e específicos, da Ciência Jurídica, tais como aqueles integrantes da interação do fato com a validade social (sociologismo jurídico), do valor com a validade ética (moralismo jurídico) e da norma com a validade técnico-jurídica (normativismo abstrato), além de elementos de domínio que traduzem uma tridimensionalidade concreta ou específica: fato/eficácia (aspecto do ser), valor/fundamento (aspecto do poder-ser) e norma/vigência (aspecto do dever-ser). 
PERCEPÇÃO CIENTÍFICA DO DIREITO

\section{Caracterização Particular da Ciência do Direito}

De todo e exposto, resta concluir, - não obstante algumas acepções conceituais simplificadas (que entendem, por exemplo, a ciência "como um conjunto organizado de conhecimentos relativos a um determinado objeto, especialmente os obtidos mediante a observação e a experiência dos fatos e um método próprio") -, que toda a ciência resume-se, em última análise, a um processo de percepção valorativa objetiva (inerente ao mundo real) ou subjetiva (inerente ao mundo cultural) de um dado fato natural ou social, produzindo, em conseqüência, uma norma explicativa (descritiva da realidade física) ou de projeção não-comportamental (descritivas e analíticas da realidade histórica, cultural e social) e comportamental (descritivas e analíticas de condutas humanas).

Nesse aspecto, é cediço concluir que toda a ciência é, em síntese, interpretativa em uma tradução abrangente, tendo em vista que o escopo de atuação científica se processa exatamente através da interpretação de fenômenos naturais ou sociais (culturais). Desta feita, a chamada valoração intrínseca de um dado fato (natural ou social), criando uma tese ou norma, nada mais é do que o resultado último de uma interpretação em sentido amplo. Por efeito, quando se afirma que uma determinada ciência é classificada como não-hermenêutica isto não significa dizer que inexiste, in casu, interpretação, mas apenas que não se processa, na hipótese, um mecanismo de "sobreinterpretação" (ou dupla interpretação), caracterizador do denominado processo hermenêutico.

Nesse diapasão analítico, é lícito afirmar que a denominada ciência hermenêutica - de que o Direito é o melhor exemplo - se caracteriza, sobremodo, pela efetiva existência de um autêntico processo complexo de interpretação. Por efeito, vale dizer que inicialmente há, como em todas as demais ciências, a valoração intrínseca de um fato criando uma dada norma ou tese (fase legislativa); todavia, de forma diversa das demais espécies científicas, a norma produzida pelo sistema interpretativo básico não pode ser, de imediato, aplicada, sendo 
necessária uma espécie de "sobreinterpretação" (ou seja, a norma concebida originariamente é reinterpretada através de um novo e diferente processo) para se chegar, finalmente, à interpretação final e definitiva, no contexto específico de uma "verdade relativa", por intermédio de uma fase judiciária.

A este fenômeno particular e próprio do Direito é que convencionalmente a doutrina costuma denominar de interpretação normativa ou hermenêutica jurídica e que, em face de sua inerente complexidade, será estudado em capítulo estanque.

Diagrama 8: Processo Interpretativo Concernente à Ciência do Direito

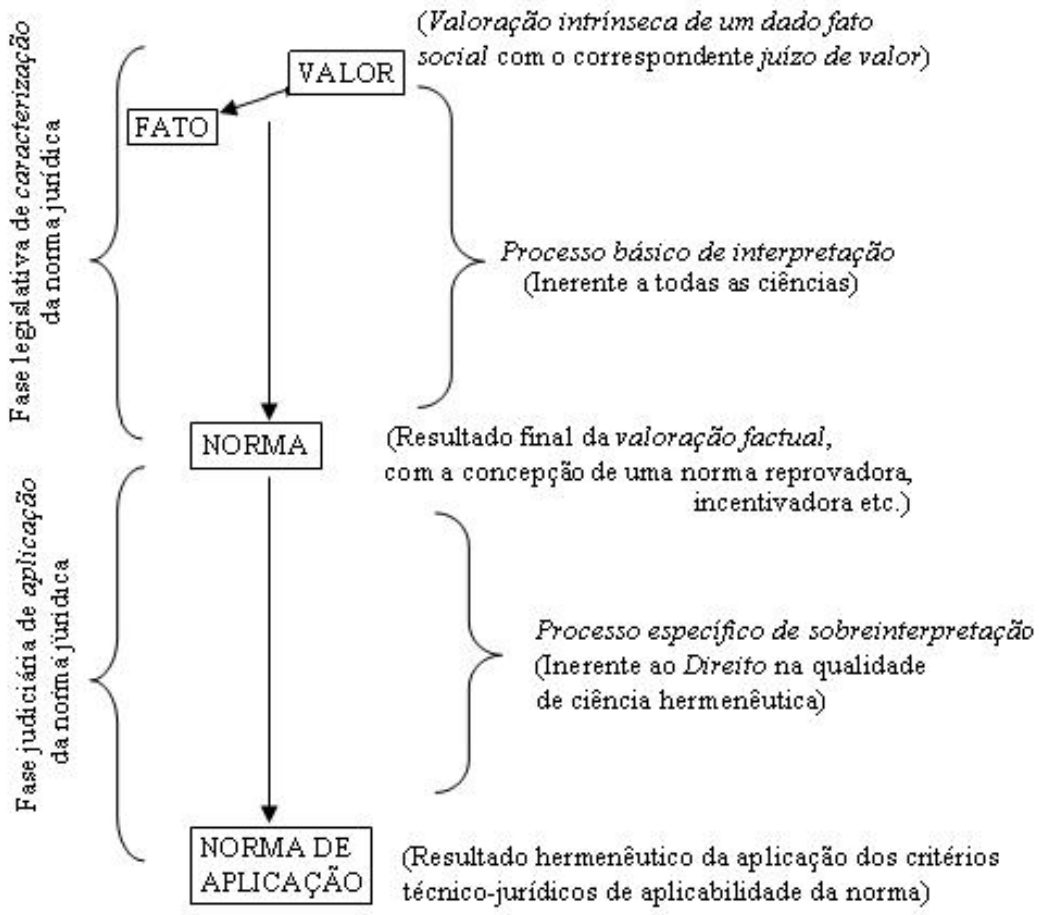


PERCEPÇÃO CIENTÍFICA DO DIREITO

\section{Ciência Axiológica}

Da mesma forma que o Direito se caracteriza, sob o prisma hermenêutico, como uma ciência de "duplo processo interpretativo" (ou "sobreinterpretação"), igualmente se processa como uma ciência de valoração factual ampliada, ou mesmo de "sobrevaloração".

Isto significa, em linguagem objetiva, que, no âmbito da Ciência do Direito, o processo de valoração intrínseca de um fato, concebendo uma dada norma, não se restringe a um espectro valorativo (de cunho científico) nitidamente objetivo (ou exclusivamente interpretativo), mas, ao contrário, necessita da imposição de valores sociais (derivados da ética, da moral etc. e que, necessariamente, são mutáveis no tempo e no espaço) e de valores intrínsecos (tais como segurança, justiça, ordem etc.)

Como os valores axiológicos do Direito podem, inclusive (em dadas circunstâncias), ser antagônicos (segurança versus justiça, por exemplo), incumbe ao processo valorativo (de feição axiológica) particular do Direito a busca permanente de uma solução conciliadora, representada, em última análise, pela caracterização dicotômica dos diferentes ramos científicos do Direito (direito penal, civil, tributário etc.) que ponderam, de maneira propositadamente desigual, os diferentes valores intrínsecos a cada dada situação efetiva. ${ }^{10}$

\section{Especificidades da Ciência Jurídica}

A percepção do Direito como inexorável ramo científico, todavia, não é, por si só, suficiente para a plena compreensão do fenômeno jurídico à luz das necessidades de superação das múltiplas questões que se apresentam. Muito pelo contrário, resta fundamental que o estudioso da matéria seja capaz de entender, de forma amplamente satisfatória, as três características basilares do Direito como ciência: projeção comportamental, axiologia e hermenêutica.

A primeira - projeção comportamental - alude ao fato de que a preocupação vital do Direito resume-se, acima de tudo, em 
moldar comportamentos individuais e grupais, a partir de um quadro de idéias e valores (mutáveis no tempo e no espaço), idealizado pelo conjunto da sociedade, representada pelos seus legisladores. ${ }^{11}$

Assim é que o Direito está, de modo constante e permanente, a orientar as condutas humanas em sociedade, a partir de suas normas jurídicas que são produzidas pelo conjunto da sociedade (ainda que através de seus representantes eleitos para tanto) e aplicadas (interpretadas) por um corpo técnico de julgadores, quando da eventualidade da existência do conflito (derivado da não-compreensão dos exatos termos da norma e/ou do efetivo e intencional descumprimento da mesma).

A segunda - a axiologia - corresponde à inconteste existência de uma infinidade de valores intrínsecos ao Direito, donde se destacam, preponderantemente, os valores da justiça e da segurança.

Como ambos os valores são igualmente importantes, tratou o Direito (originalmente, uma inconteste realidade unitária) de se ramificar, permitindo o estabelecimento a priori de eventuais possibilidades de prevalência de um valor sobre o outro, quando preexiste a hipótese de conflito valorativo.

Desta maneira, prevalece, em última instância, a verdade real (em nome do valor da justiça) nas questões instrumentalizadas pelo Direito Processual Penal, ao passo que prepondera, em última análise, a verdade ficta, formal ou presumida (em nome do valor da segurança) nas questões (sobretudo patrimoniais) instrumentalizadas pelo Direito Processual Civil. ${ }^{12}$

A terceira - hermenêutica - indica, sobremaneira, a existente interação funcional entre a apriorística parcela legislativa do Direito e a subseqüente parcela judiciária, responsável última pela interpretação (e aplicação, nos eventuais conflitos) das normas jurídicas produzidas pelos representantes do povo (na qualidade de titular do Poder Político)..$^{13}$

Muito embora o conhecimento dessas três características basilares do Direito como ciência seja absolutamente fundamental para o entendimento e a compreensão última do fenômeno jurídico, é exatamente esta última característica (a hermenêutica jurídica) e sua indispensável e plena compreensão - o fator primordial para o 
completo êxito deste objetivo, posto que tal característica atinge o âmago da concepção estrutural do Direito.

Aliás, neste particular, cumpre assinalar, de modo veemente, que o objeto específico (em seu sentido mais restritivo) do conteúdo dos cursos jurídicos cinge-se, preponderantemente (se não exclusivamente) à interpretação (e aplicação) da norma jurídica, produzida pelo legislador, e não propriamente à caracterização originária da lei (em seu sentido amplo) ou do próprio Direito, devendo, neste aspecto, serem afastadas, com sinérgica repulsa, quaisquer teses (ou posições) excêntricas (e altamente controvertidas), como a do propalado Direito Alternativo ou Direito Insurgente.

Diagrama 9: Características Basilares do Direito como Ciência

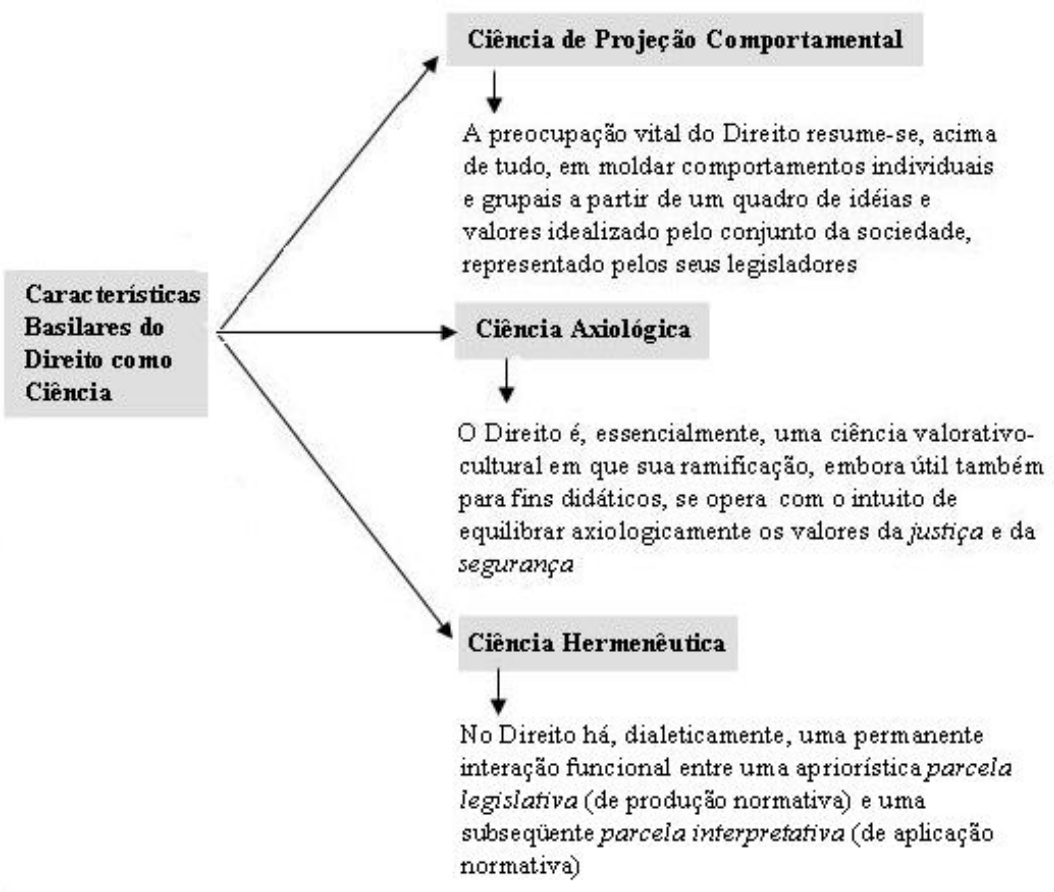

HISTÓRIA, São Paulo, 28 (2): 2009 
Diagrama 10: Direito como Ciência de Projeção Comportamental

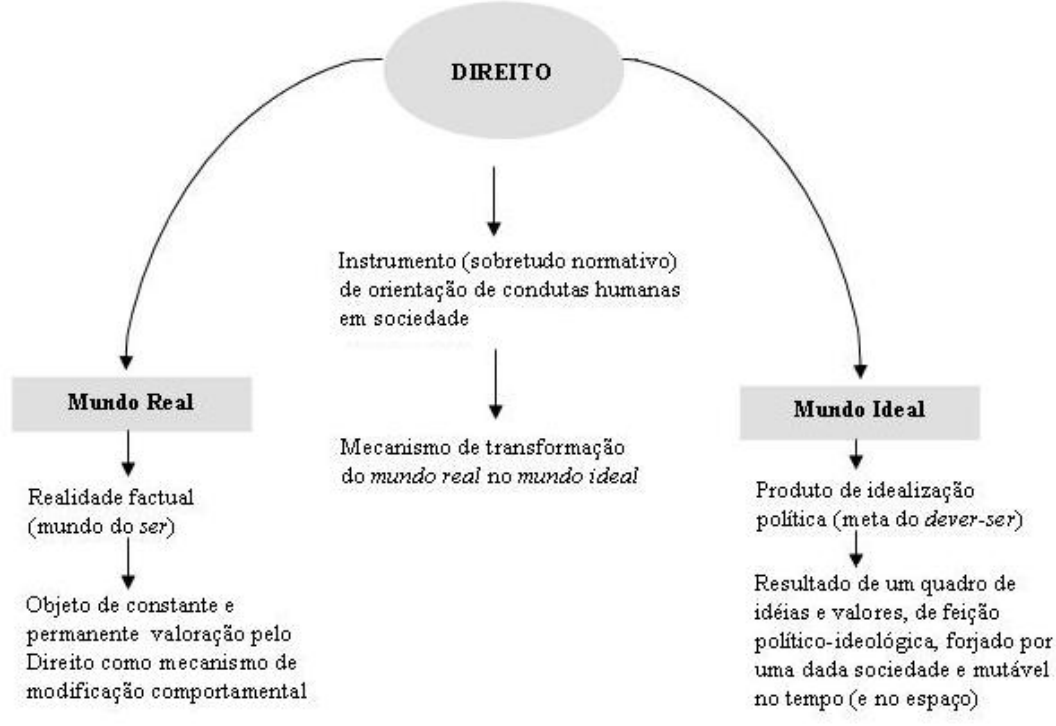

Diagrama 11: Direito como Ciência Axiológica

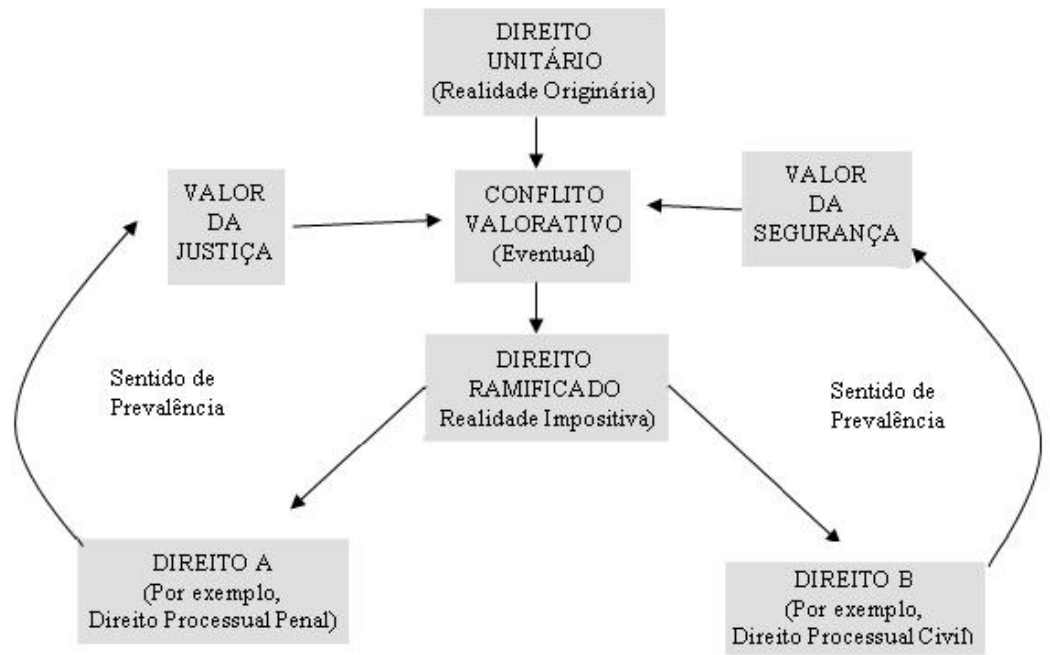




\section{Diagrama 12: Direito como Ciência Hermenêutica}

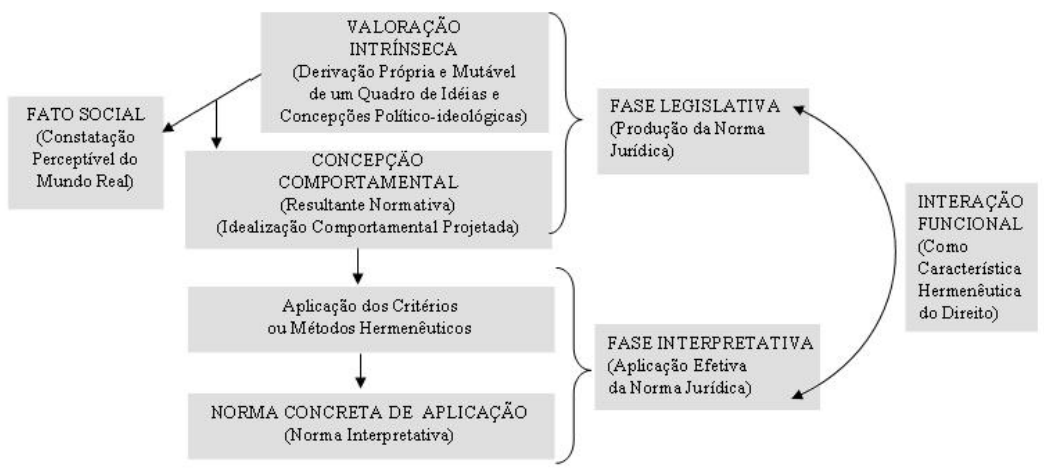

\section{Referências Bibliográficas}

COMTE, Augusto. Cour de Philosophie Positive. Paris, 1949.

DILTHEY, Wilhelm. Introduction a L'etude des Sciences Humaines. Paris, 1942.

DINIZ, Maria Helena. Compêndio de Introdução à Ciência do Direito. $12^{\mathrm{a}}$ ed., São Paulo: Saraiva, 2000.

FERRAZ JR., Tércio Sampaio. Direito, Retórica e Comunicação. Saraiva: São Paulo, 1973.

JACQUES, Paulino. Curso de Introdução ao Estudo do Direito. Forense: Rio de Janeiro, 1978.

KELSEN, Hans. Teoria Pura do Direito. Trad. de João Baptista Machado. Coimbra: Arménio Amado Editor, 1974.

LIMA, Hermes de. Introdução à Ciência do Direito. 27ª ed., Rio de Janeiro: Freitas Bastos, 1983.

REALE, Miguel. Lições Preliminares de Direito. 24a ed., Saraiva: São Paulo, 1999. 
FRIEDE, Reis. Scientific Perception of Law. História, v.28, n.2, p.235-266, 2009.

\begin{abstract}
This article examines, first, the majority position of the doctrine that the law is to be authentic and genuine autonomous science, addressing the concept of science, the binary classification of sciences, as well as other classifications related to science, through the following, the classification of the Science of Law, to extract the important lessons derived from this perception. Later, going to the legal analysis of the axiological and the projected behavioral law, the tridimensionality the law, the particular characterization of the Science of Law and, finally, the specific nature of legal science.
\end{abstract}

Keywords: Law; Autonomous Science; Classification; Axiological.

\title{
NOTAS
}

1 Nesse contexto, por força do raciocínio binário, é lícito, inclusive, consignar o conceito antagônico à ciência que se traduz modernamente pela crença. Enquanto a ciência, reconhecendo que não possui a verdade, objetiva, de forma constante e permanente, encontrá-la (através da busca incessante da explicação verdadeira dos fenômenos fáticos (de valoração objetiva e subjetiva) e de suas consequentes ocorrências no mundo real e cultural), a crença, por sua vez, ciente de que já possui a verdade (ou seja, a correta explicação para os fenômenos fáticos do mundo real), simplesmente impõe a sua explicação (interpretação), como única e insuperável tradução da realidade, permitindo, neste sentido, a concepção básica da denominada fé (que é sempre imposta), como fator último a impedir o próprio desenvolvimento da crença. Não é por outra razão, inclusive, que a essência da fé (na qualidade de fator basilar da crença) se traduz pelo "acreditar em algo que não pode ser provado", tornando, por efeito, toda crença (como, por exemplo, a religião) igualmente válida (não permitindo, consequentemente, padrões de comparação qualitativa) e determinante sob a ótica de sua própria abrangência.

${ }^{2}$ Assim é que nos primórdios da Física, a melhor explicação científica 
para o fenômeno da queda de um objeto em direção ao chão não passava pela atual e complexa teoria da gravitação universal, preferindo os "cientistas" da época, por ausência de melhor interpretação, entenderem $o$ fato (na qualidade de efetivo acontecimento no mundo real) através da singela concepção da existência de uma pretensa "mão invisível" que simplesmente empurrava todo e qualquer objeto em direção ao solo. Mas mesmo com todo o desenvolvimento da Ciência da Física, o homem ainda não foi capaz de explicar, de forma inequívoca, dentro de seu contexto de juízo de realidade, dotado de valoração objetiva, o simples fato da queda de um objeto em direção chão, considerando, sobretudo, que a vigente lei da gravidade (corolário da teoria da gravitação universal) parte de um princípio básico de suposta validez universal, mas amplamente contestável, que poderia ser resumido, não obstante algumas complexidades que deixaremos ao largo, da seguinte maneira: um corpo de massa menor é sempre atraído em direção ao corpo de massa maior, determinando, em conseqüência, que qualquer objeto (de massa relativa desprezível) simplesmente "caia" em direção ao centro do planeta (que possui massa infinitas vezes maior), sendo contido apenas pelo obstáculo natural que é exatamente a sua superfície (ou seja, o chão). Como o pressuposto básico da atração gravitacional como concebida na atualidade contemporânea, pressupõe a existência de corpos com massa, a Física de hoje simplesmente não é capaz de explicar a descomunal atração gravitacional que exerce os chamados "buracos negros", na qualidade de corpos celestes desprovidos de matéria, e, por conseqüência, de massa, na concepção clássica de "massa branca".

${ }^{3}$ É evidente que os denominados Princípios Gerais do Direito não são universais ou mesmo permanentes (até porque, os fenômenos sociais que os instruem são nitidamente mais complexos que os fenômenos naturais, objetos de outras ciências) muito embora, no mundo atual de notável capacidade de comunicação e intercâmbio, essa realidade tenda naturalmente a um ponto de aproximação semelhante a pretensa universalização de concepções tipicamente estudados pela Física, Química, Astronomia etc. O próprio conceito axiológico de justiça, como valor intrínseco do Direito, é conveniente ressaltar, vem sendo, de modo perceptível, permanentemente universalizado, não obstante as diversas culturas e os diferentes estágios evolutivos das várias sociedades em convivência temporal comum. Por outro lado, é também 
importante consignar que as ciências dotadas de juízo de valor (valoração subjetiva), como o Direito, são inerentes ao denominado mundo cultural, em que as preocupações valorativas possuem inconteste natureza subjetiva.

4 É exatamente neste sentido que alguns autores observam a existência, em matéria científica, das denominadas "verdades relativas", ou, em outras palavras, "verdades" com validez limitada ou restrita, no tempo e no espaço, a uma dada e/ou considerada situação fática. Por outro prisma, como o objeto das ciências sociais (culturais) é mais complexo do que o das ciências naturais, considerando, neste contexto analítico, não só a célebre afirmação de Wilhelm Dilthey (Introduction a L'etude des Sciences Humaines, Paris, 1942) de que "a natureza se explica, enquanto que a cultura se compreende" mas, sobretudo, a constatação inequívoca de que o fato social abrange relações múltiplas (mecânicas, físicas, químicas, biológicas, etc.), deduz-se, sem muito esforço, que a sua mobilidade é muito maior que a relativa às ciências naturais, gerando uma falsa impressão de que suas conclusões interpretativas são menos válidas ou mesmo desprovidas de qualquer grau de cientificidade. A verdade, entretanto, é que ambas as ciências (naturais e sociais (culturais)) são, por definição, inexatas (pois buscam, de forma constante e permanente, as suas respectivas verdades interpretativas), diferenciando-se apenas no foco de associação dos fenômenos e, em conseqüência, no lapso temporal associado que, no caso das ciências naturais (por se tratar de fenômenos de menor complexidade relacional), são mais longos, originando uma primeira (e equivocada) impressão de que não são variáveis e, portanto, traduzem uma realidade fixa e exata.

${ }^{5}$ Sob uma ótica puramente matemática, neste sentido, seria até mesmo lícito afirmar que o raciocínio binário corresponde, como uma sinérgica limitação humana, a uma progressão geométrica de razão igual a dois. Em essência, o número a índice $n$, último numeral da progressão, corresponderia ao infinito, demonstrando, claramente, a efetiva possibilidade humana de desenvolvimento. Porém, a velocidade deste mesmo desenvolvimento, correspondente à razão q da progressão, seria o menor possível, ou seja dois, equivalente numeral ao raciocínio binário.

${ }^{6}$ É importante esclarecer que a nomenclatura usual designativa dos diversos tipos de ciência não guarda o necessário rigor terminológico que deve, em última análise, traduzir as características intrínsecas de 
cada modalidade científica. Assim, seria absurdo supor a existência de uma pretensa ciência exata, considerando o próprio conceito contemporâneo de ciência que se coaduna, de modo geral, com a "busca da verdade". De igual forma, sem qualquer precisão designativa, apresenta-se a expressão ciência humana, posto que toda ciência é um produto humano de valoração intrínseca a um fato, concebendo uma regra explicativa (norma), associada, por seu turno, a um juízo de realidade ou a um juízo de valor. Ainda assim, é forçoso reconhecer que não há como afastar, de modo definitivo, estas nomenclaturas tradicionais (porém, atécnicas), devendo pois, os estudiosos do tema (e demais interessados) procurar conviver com tais expressões, através de uma "virtual tradução" de seus verdadeiros (e respectivos) sentidos designativos.

7 Conforme já mencionamos, a partir da observação de fatos da natureza, o homem descreve interpretativamente determinadas normas que retratam, através de uma percepção objetiva, a explicação lógica relativa aos fenômenos naturais, concebendo os chamados "juízos de realidade". Neste particular, é cediço deduzir que os corpos providos de massa "caem" (na verdade se dirigem ao centro do planeta), em função de uma construção normativa, cuja síntese conclusiva aponta para a explicação teórica da lei da gravitação universal (cujo corolário mais conhecido denomina-se lei da gravidade), da mesma maneira que os gases, quando submetidos ao calor, se dilatam, através de leis concebidas pelo homem por intermédio de uma valoração objetiva da realidade fática inerente ao denominado mundo do ser, em que a participação humana, embora tenha inegável caráter de percepção valorativa, é sempre dirigida objetivamente a explicação dos fenômenos inerentes ao mundo como ele de fato se apresenta, sem qualquer consideração subjetiva (juízo de valor propriamente considerado), posto que seu único objetivo é extrair juízos perceptivos de realidade, criando normas físicas com o intuito de sedimentar (e desenvolver) os conhecimentos adquiridos. A partir da observação dos fatos sociais, em virtual oposição, todavia, o homem descreve interpretativamente, determinadas normas que refletem, através de uma percepção subjetiva, não a explicação lógica inerente ao mundo natural, mas, ao contrário, a valoração efetiva derivada da realidade cultural em que se encontra inserido, produzindo normas de cultura (e não normas da natureza) derivadas de um juízo de valor (valoração subjetiva). Neste especial, o homem, de forma diversa do juízo de 
realidade (onde também existe uma valoração perceptível, ainda que de caráter objetivo), não mais deseja construir normatizações inerentes ao mundo como ele é (mundo do ser), mas, ao contrário, procura traduzir valores próprios (subjetivos) que projetem alterações circunstanciais capazes de interferir com a realidade, concebendo um autêntico mundo derivado que corresponde aos vários objetivos pelos quais o homem analisa a realidade fática buscando, através dos vários juízos de valor, analisá-la e modificá-la.

${ }^{8}$ A verdade é que o Direito, como ciência, possui, numa aproximação para fins didáticos, dois diferentes momentos interpretativos. $\mathrm{O}$ primeiro - comum a todas as ciências e que se processa através da tríade fato/valor/norma - caracteriza um processo tipicamente legislativo de criação da própria norma abstrata. O segundo - peculiar à chamada ciência jurídica - desenvolve um processo genuinamente judicial de aplicação efetiva da norma abstrata por meio da caracterização (através de um complexo hermenêutico de mecanismos de interpretação da norma jurídica) da norma concreta (ou efetiva).

${ }^{9}$ Sob a ótica axiológica, em particular, cumpre esclarecer que o Direito se exterioriza, no âmbito científico, através de um específico e complexo processo de valoração factual que inclui parcelas intrínsecas (notadamente a segurança das relações sócio-político-jurídicas e a busca da justiça (ou da decisão justa)), cuja ponderação se concretiza, de maneira diferenciada, por intermédio dos diversos ramos científicos do Direito. Assim, o Direito Processual, que, incontestavelmente, se constitui em uma inexorável unidade (como sempre defenderam os unitaristas (ou monistas), como Hans Kelsen), passou a ser dividido em Direito Processual Penal - no qual, no eventual confronto entre os valores axiológicos da justiça e da segurança, prepondera o valor da justiça (razão pela qual inexiste, por exemplo, prazo decadencial para o ajuizamento da competente ação autônoma de impugnação (revisão criminal) contra sentença condenatória transitada em julgado) - e em Direito Processual Não-Penal (Direito Processual Patrimonial ou Civil lato sensu) - no qual, no mesmo confronto, prepondera o valor da segurança (razão pela qual há, no âmbito do processo civil, em situação análoga, prazo decadencial de dois anos para o ajuizamento da competente ação autônoma de impugnação (ação rescisória) contra sentença transitada em julgado na esfera cível).

${ }^{10}$ Não é por outra razão que, após duas horas acaloradas de debates, o Superior Tribunal de Justiça tomou uma decisão inédita no Brasil. 
Negou o cancelamento do registro de paternidade, mesmo após um exame de DNA comprovar que um pediatra de Goiás não era o pai biológico de uma criança. A razão: a sentença já havia transitado em julgado. O STJ optou por manter a sentença para preservar a "segurança jurídica" no campo do Direito Civil. A ação foi julgada em primeira instância em 1993 e a decisão, à base de provas testemunhais, foi pelo reconhecimento da paternidade. Em segunda instância, manteve-se a decisão. E, em grau de recurso, chegou o caso ao STJ, que não julgou a ação por se tratar de matéria de prova (é conveniente lembrar que o STJ só tem competência para julgar matéria de direito). Só depois de vencidos os prazos legais em que podia recorrer, o pediatra entrou com uma ação de negação de paternidade, exigindo o exame de DNA e pedindo o cancelamento do registro civil. O exame provou que não era ele o pai. Mas aos olhos da lei era tarde demais. Prevaleceram no STJ os argumentos de que a matéria julgada deveria ser preservada, sob pena de abrir um precedente que determinaria a possibilidade de reavaliação constante de ações já julgadas, fazendo, desta feita, pois, prevalecer o princípio de segurança jurídica sobre o valor da justiça, como valor axiológico básico inerente ao Direito, considerando, sobretudo, a natureza não-penal do Direito Processual vertente à hipótese.

${ }^{11}$ Não é por outra razão que as normas incriminadoras (típicas da parte especial do Código Penal), por exemplo, não podem ser aplicadas retroativamente, posto que a preocupação fundamental do Direito não é punir e sim evitar que a conduta reprovável (e em algum momento já realizada) se repita, projetando, desta feita, o comportamento idealizado pelo conjunto da sociedade (contrário à prática da conduta considerada). Em sentido oposto, as chamadas normas permissivas têm emprego retroativo exatamente pelo fato de que a projeção de comportamentos, intrínseca ao Direito, encontra fundamento na valoração factual (valoração político-ideológica do conjunto da sociedade (através de seus representantes) sobre o fato social, concebendo a norma comportamental (norma jurídica)) que, por natureza, é sempre mutável no tempo (e no espaço) e, por esta razão, deve acompanhar os desígnios sociais mais atualizados.

${ }^{12}$ Ainda assim, deve ser esclarecido que os valores vertentes do Direito (fundamentalmente, a justiça e a segurança) não são necessariamente divergentes. Muito pelo contrário, trata-se de valores harmônicos e convergentes que, apenas em dadas situações concretas, tornam-se 
divergentes, obrigando o Direito, como realidade axiológica, a resolver o eventual conflito valorativo. Assim é que, em essência, o Direito Processual Civil, em relação ao Direito Processual Penal, busca igualmente a verdade real; apenas, não a encontrando, sua disciplina autoriza o julgador a sentenciar com base na verdade presumida. Aliás, a maior prova da convergência axiológica dos valores intrínsecos ao direito pode ser deduzida partindo-se de uma premissa segundo a qual cada grau jurisdicional subsequente (posterior) aperfeiçoa o anterior, forjando a concepção hipotética de que, para se ter um decisão absolutamente justa, seriam necessário $\mathrm{n}$ graus, quando $n$ tende ao infinito ( $¥)$. Ora, como a existência humana é inexoravelmente finita, tal concepção - abstrata e hipoteticamente justa - seria, na prática, absolutamente injusta, posto que todos os jurisdicionados (e demais interessados) deixariam de existir antes da prolação final da sentença. A restrição do número de graus de jurisdição - uma inconteste imposição do fator segurança -, por efeito, coaduna, neste contexto, perfeitamente com os ditames mais sublimes do valor da justiça, demonstrando claramente o relativo equilíbrio axiológico do Direito.

${ }^{13}$ A idéia central in casu corresponde, em termos aproximados, à noção da separação funcional do exercício do Poder Político e, em parte, ao festejado mecanismo de freios e contrapesos, considerando que, na hipótese, a parcela responsável pela criação e edição das leis (Poder Legislativo) não pode interpretar e aplicar as mesmas, ao passo que a parcela responsável pela interpretação e aplicação das leis (Poder Judiciário, em última análise) não pode fazê-lo, exceto com base na norma legitimamente produzida pelo legislador. Não é por outro motivo que, não obstante seja pacífico o entendimento de que o julgador deve sempre buscar a decisão justa, o mesmo jamais pode obter o resultado almejado senão com base na lei (ou nas leis), legítima e constitucionalmente produzidas pelo legislador. Também, a propósito do tema, vale consignar que não é só o julgador que aplica e interpreta a norma jurídica. Muito pelo contrário, todos os operadores do Direito (advogados, membros do Ministério Público, juízes etc.) e até mesmo os cidadãos são potenciais aplicadores e intérpretes (o primeiro grupo, de forma técnica, e o segundo, de modo leigo), sendo certo que, no eventual conflito, no entanto, a última palavra (no que tange à interpretação e à aplicação das normas jurídicas) será sempre do Judiciário (e, consequentemente, de seus membros).

Artigo recebido em 08/2009. Aprovado em 11/2009. 